\title{
UNIÃO HOMOAFETIVA E A ATUAÇÃO DO SUPREMO TRIBUNAL FEDERAL NA CONCRETIZAÇÃO DE DIREITOS FUNDAMENTAIS
}

\author{
LAÍS GOMES BERGSTEIN ${ }^{1}$
}

\begin{abstract}
RESUMO: O fenômeno da constitucionalização dos direitos e a evolução do Estado para o modelo de Bem-Estar Social culminaram na politização da função dos magistrados, incumbindo-os das árduas tarefas de resolver litígios e proteger as normas Constitucionais até mesmo em face da intervenção dos Poderes Executivo e Legislativo. O presente estudo analisa a atuação do Poder Judiciário a partir da recente decisão do Supremo Tribunal Federal de reconhecer a união estável entre pessoas do mesmo sexo, abordando as questões da politização da atuação magistrática e da judicialização da política debatidas em amplo espectro pela sociedade civil. Conclui-se que a politização é inerente à função jurisdicional, uma vez que a nova ordem Constitucional e a realidade brasileira demandam do magistrado, independentemente do Tribunal ou Corte no qual esteja inserido, que interprete as leis e normas jurídicas de modo a efetivar os preceitos constitucionais, atuando ativamente em prol da sociedade.
\end{abstract}

PALAVRAS-CHAVE: Direitos Humanos; Poder Judiciário; Competência Legislativa; Supremo Tribunal Federal; Judicialização.

ABSTRACT: The phenomenon of rights' constitutionalization and the evolution of the State model led to the politicization of the judiciary function, charging judges with the arduous task of settling disputes and protecting the Constitution even in against intervention by the Executive and Legislature States. This study examines the role of the judiciary from the recent decision of the Brazilian Supreme Court to recognize the stable union between people of the same sex, addressing issues of politicization of acting magistrates and the legalization of politics, both discussed in a broad spectrum of civil society. We conclude that politicization is inherent in the judicial function, due to the fact that the new Brazilian constitutional order and the Brazilian reality demands the magistrate interprets the laws and legal standards in order to give effect to the constitutional provisions, working actively in favor of society.

KEYWORDS: Human Rights; Judiciary; Legislative Competence; Brazilian Supreme Court; Judicialization.

Comentário de Jurisprudência recebido em 24.08.2011. Comentário de Jurisprudência aceito para publicação em 20.12.2011.

${ }^{1}$ Mestranda em Direito Econômico e Socioambiental pela Pontifícia Universidade Católica do Paraná, Curitiba-PR. Bolsista da Coordenação de Aperfeiçoamento de Pessoal de Nível Superior (CAPES). Advogada do Escritório Professor René Dotti, em Curitiba-PR. lais@dotti.adv.br 
SUMÁRIO: Introdução; 1. O Supremo Tribunal Federal no Brasil; 2. União Homoafetiva: a decisão do STF; 3. Usurpação da Competência Legislativa?; 4. O Poder Judiciário no Estado Moderno; Conclusão; Referências.

SUMMARY: Introduction; 1. The Brazilian Supreme Court; 2. Same-sex Civil Union: the Supreme Court's decision; 3. Is it a Legislative Competence's Usurpation?; 4. The Judiciary Power in the Modern State; Conclusion; References.

\section{INTRODUÇÃO}

Rui Barbosa já afirmou que "O Direito não jaz na letra morta das leis: vive na tradição judiciária, que as atrofia, ou desenvolve." '. O desenvolvimento do Estado de Bem-Estar Social no Brasil politizou a função dos magistrados incumbindo-os das árduas tarefas de dirimir litígios do modo socialmente mais justo e de proteger as normas Constitucionais até mesmo da intervenção dos Poderes Executivo e Legislativo. As palavras de Rui Barbosa, portanto, bem traduzem a dialética do papel do magistrado no Estado moderno, que, no ápice da sua consciência, apresenta-se aos jurisdicionados com muito mais proeminência do que no modelo juge bouche de la loi como antes era conhecido, possibilitando a concretização dos direitos humanos expressos na Constituição.

Uma recente decisão proferida pelo Tribunal Pleno do Supremo Tribunal Federal colocou em perspectiva os limites e contornos da competência concedida à chamada Corte Constitucional brasileira. Dada a relevância das questões deliberadas, ao todo, por dez Ministros ${ }^{3}$, a sociedade civil envolveu-se em um amplo debate acerca da competência e da legitimidade democrática do Supremo para atribuir interpretação diversa à literalidade de um dispositivo legal, além da aparente supressão, pelo Poder Judiciário, de um silêncio legislativo.

O presente estudo analisa, no contexto do Estado Moderno, a evolução do papel dos magistrados brasileiros e as mudanças decorrentes da constitucionalização e da respectiva necessidade de efetivação de direitos fundamentais, o que culminou no fenômeno conhecido por judicialização.

\section{O SUPREMO TRIBUNAL FEDERAL NO BRASIL}

O Supremo Tribunal Federal é considerado uma Corte Constitucional Federal em razão da competência que Ihe é atribuída pela Constituição da República de 1988. Nelson Nery Junior, contudo, sustenta que o perfil do STF, enquanto Tribunal Constitucional, não é o melhor, especialmente pelo fato de seus membros serem nomeados exclusivamente pelo Chefe do Poder Executivo, sem critérios de proporcionalidade ou de representatividade dos demais Poderes (note-se que o Senado apenas aprova ou rejeita a indicação proposta pelo Presidente da República), assim como em razão dos

\footnotetext{
${ }^{2}$ MATOS, Miguel. Migalhas de Rui Barbosa. v. 1. São Paulo: Migalhas, 2010. p. 424.

${ }^{3} \mathrm{O}$ décimo primeiro Ministro, Dias Toffoli, não participou do julgamento.
} 
cargos de Ministros serem vitalícios. ${ }^{4}$ Acredita-se que para que uma Corte seja legitimamente Constitucional é necessário que seus membros sejam representativos dos três Poderes, e não de apenas um deles.

A Corte Constitucional Alemã, por exemplo, constitui-se como um Tribunal suprapartidário, na medida em que é formada por membros indicados pelos três Poderes, com mandatos pelo prazo determinado de doze anos e sendo vedada a recondução ao cargo. Além disso, a Corte situa-se no organograma precisamente ao lado dos Poderes Executivo, Legislativo e Judiciário, ou seja, não é órgão do Judiciário e não sofre nenhum tipo de ascensão sobre o Executivo ou o Legislativo. ${ }^{5} \mathrm{~A}$ bem da verdade, conforme relato de Miguel Reale, cogitou-se, ao tempo da Constituinte de 1988, a hipótese de criação no Brasil de uma Corte Constitucional soberana, eletiva e de feitio puramente político, a opção que prevaleceu, contudo, foi pela manutenção do Supremo Tribunal Federal, realizando-se, no entanto, algumas mudanças essenciais nas suas atribuições. $^{6}$

O Supremo Tribunal Federal também tem natureza bastante diversa da Suprema Corte norte-americana, em que pese a existência de diversas características comuns. Nos Estados Unidos, verifica-se, por exemplo, que até a presente data, não existe controle abstrato de constitucionalidade das leis, mas apenas o controle concreto, com o objetivo de se manter o equilíbrio e a harmonia entre os três Poderes. A primeira impressão sobre o tema geralmente é em sentido contrário, contudo, nota-se que até mesmo o caso Marbury vs. Madison, no qual a Suprema Corte afirmou que o Judiciário pode exercer controle de constitucionalidade, era caso concreto. ${ }^{7}$ José Reinaldo de Lima Lopes ressalta que a Suprema Corte norte-americana é nitidamente um poder de Estado em razão da prática política instaurada a partir da presidência do juiz Marshall. A indicação de um juiz para integrar a Corte norte-americana é ato notoriamente político, envolve debates no Congresso, pela imprensa e manifestações da sociedade civil. ${ }^{8}$ Difere, portanto, substancialmente do Supremo Tribunal Federal no Brasil, a despeito das corriqueiras comparações.

Assim, a atuação do Supremo Tribunal Federal no Brasil é peculiar, muito diferente das demais Cortes às quais é correlacionado, embora se admita a existência de pontos de convergência em relação à sua competência.

\footnotetext{
${ }^{4}$ NERY JUNIOR, Nelson. Princípios do Processo na Constituição Federal: processo civil, penal e administrativo. 9. ed., rev., atual. e amp. São Paulo: Revista dos Tribunais, 2009. p. 44-45.

${ }^{6}$ REALE, Miguel. Liberdade e Democracia: em torno do anteprojeto da Comissão Provisória de Estudos Constitucionais. São Paulo: Saraiva, 1987. p. 102.

${ }^{7}$ NERY JUNIOR, Nelson, op. cit., p. 47-48.

${ }^{8}$ LOPES, José Reinaldo de Lima. A Função Política do Poder Judiciário. In: FARIA, José Eduardo. Direito e Justiça: a função social do Judiciário. São Paulo: Ática, 1989. p. 135.
} 


\section{UNIÃO HOMOAFETIVA: A DECISÃO DO STF}

Um julgamento recentemente concluído pelo Supremo Tribunal Federal colocou em perspectiva os contornos e os limitas da atuação da Corte que é incumbida do relevante dever de guarda da Constituição da República ${ }^{9}$. Trata-se do reconhecimento da possibilidade jurídica de constituição de união estável entre pessoas do mesmo sexo. É importante, para fins de contextualização, que seja feito um breve histórico sobre os fatos e medidas que culminaram nesta decisão.

O Governador do Estado do Rio de Janeiro, em 27.02.2008, propôs, perante o Supremo Tribunal Federal, a Arguição de Descumprimento de Preceito Fundamental (ADPF) $\mathrm{n}^{\circ}$ 132, fundada no descumprimento dos preceitos constitucionais de igualdade (art. $5^{\circ}$, caput, CF) e de liberdade (art. $5^{\circ}, \mathrm{II}, \mathrm{CF}$ ), assim como nos princípio da dignidade da pessoa humana (art. $\left.1^{\circ}, I V, C F\right)$ e da segurança jurídica (art. $5^{\circ}$, caput, CF). A arguição indicava, dentre os atos do Poder Público causadores de lesão, o "[...] conjunto de decisões judiciais proferidas por tribunais estaduais, inclusive e notadamente o do Rio de Janeiro, que negam às uniões homoafetivas o mesmo regime jurídico das uniões estáveis." ${ }^{10}$

Em 02.07.2009, a Procuradora-Geral da República ajuizou a ADPF $n^{\circ} 178$, que posteriormente foi conhecida e autuada como a Ação Declaratória de Inconstitucionalidade (ADI) $n^{\circ} 4277$, visando à declaração da obrigatoriedade do reconhecimento da união de pessoas do mesmo sexo como entidade familiar quando atendidos os requisitos impostos para a constituição de união estável. Além disso, a ação pretendia a declaração de que os mesmos direitos e deveres atribuídos aos companheiros nas uniões estáveis estendem-se aos companheiros nas uniões homoafetivas.

Em razão da evidente conexão entre as duas ações, desde março de 2011 os autos foram apensados e passaram a tramitar em conjunto, sob a relatoria do Ministro Carlos Ayres Britto, o qual ressaltou que a partir da união de ambas as ações, o "[...] Plenário terá bem mais abrangentes possibilidades de, pela primeira vez no curso de sua longa história, apreciar o mérito dessa tão recorrente quanto intrinsecamente relevante controvérsia em torno da união estável entre pessoas do mesmo sexo, com todos os seus consectários jurídicos" ${ }^{\prime 11}$.

\footnotetext{
9 "Art. 102. Compete ao Supremo Tribunal Federal, precipuamente, a guarda da Constituição, cabendo-Ihe: [...]". (BRASIL. Constituição da República Federativa do Brasil de 1988. Disponível em: <http://www.planalto.gov.br/ccivil 03/constituicao/constitui\%C3\%A7ao.htm> Acesso em: 01 ago. 2011) ${ }^{10}$ BRASIL. Supremo Tribunal Federal, Arguição de Descumprimento de Preceito Fundamental $n^{\circ}$ 132, do Rio de Janeiro. Relator: Min. Ayres Britto, Julgada em: 05.05.2011. Disponível em: $<$ http://redir.stf.jus.br/estfvisualizadorpub/jsp/consultarprocessoeletronico/ConsultarProcesso Eletronico.jsf?seqobjetoincidente=11872 > Acesso em: 20 jul. 2011.

${ }^{11}$ Voto do senhor Ministro Ayres Britto no julgamento da Arguição de Descumprimento de Preceito Fundamental $\mathrm{n}^{\circ}$ 132, do Rio de Janeiro, julgada em: 05.05.2011, pelo Supremo Tribunal Federal. Disponível em: <http://www.stf.jus.br/portal/cms/verNoticiaDetalhe.asp?id Conteudo=178792\&caixa Busca=N> Acesso em: 25 jul. 2011.
} 
Assim, no início de maio de 2011, os Ministros do Supremo Tribunal Federal, por unanimidade de votos, julgaram procedentes ${ }^{12}$ os pedidos aduzidos na ADI no 4.277 e na ADPF $n^{\circ} 132$, atribuindo eficácia erga omnes e efeito vinculante à decisão e autorizando os Ministros a decidirem monocraticamente sobre o mesmo tema, independentemente da publicação do acórdão. Nos termos do voto do Min. Relator, Carlos Ayres Britto, a decisão de atribuir os efeitos da união estável à união entre pessoas do mesmo sexo fundou-se na técnica da interpretação conforme a Constituição, para o fim de excluir do artigo 1.723 "[...] qualquer significado que impeça o reconhecimento da união contínua, pública e duradoura entre pessoas do mesmo sexo como 'entidade familiar', entendida esta como sinônimo perfeito de 'família'." 13

Para Luís Roberto Barroso, que falou perante o plenário do STF em nome do autor da ADPF $n^{\circ} 132$, "As relações homoafetivas existem e continuarão a existir, independentemente do reconhecimento jurídico positivo do Estado. Se o direito se mantém indiferente, de tal atitude emergirá uma indesejada situação de insegurança." ${ }^{14}$ Outrossim, Rogéria Dotti, ao discorrer sobre o tema alguns dias antes da referida decisão do STF, ensinou que "A vida é maior que o Direito. Este existe para servir aquela, e não o contrário." E concluiu: "Comunhão de vida significa afeto, solidariedade e objetivos comuns. Não pressupõe, necessariamente, a diferença sexual, nem tampouco a possibilidade de gerar filhos." ${ }^{15}$

A inédita decisão do Supremo teve grande repercussão na sociedade civil. Magistrados de todo o país passaram a atribuir efeitos legais à união homoafetivas, a qual começou a ser formalizada também por escritura pública firmada por Tabeliães de Notas e ensejou, inclusive, decisões autorizando a realização de casamento civil entre pessoas no mesmo sexo, embora esta questão não tenha sido objeto da decisão do Supremo.

\footnotetext{
${ }^{12}$ Transcreve-se a síntese do resultado do julgamento: "[...] o Tribunal conheceu da Arguição de Descumprimento de Preceito Fundamental 132 como ação direta de inconstitucionalidade, por votação unânime. Prejudicado o primeiro pedido originariamente formulado na ADPF, por votação unânime. Rejeitadas todas as preliminares, por votação unânime. Em seguida, o Tribunal, ainda por votação unânime, julgou procedente as ações, com eficácia erga omnes e efeito vinculante, autorizados os Ministros a decidirem monocraticamente sobre a mesma questão, independentemente da publicação do acórdão." (BRASIL. Supremo Tribunal Federal, Arguição de Descumprimento de Preceito Fundamental no 132, do Rio de Janeiro, julgada em: 05.05.2011. Disponível em: <http://redir.stf.jus.br/estfvisualizadorpub/jsp/consultarprocesso eletronico/ConsultarProcessoEletronico.jsf?seqobjetoincidente=11872 > Acesso em: 20 jul. 2011). ${ }^{13}$ Voto do senhor Ministro Ayres Britto no julgamento da Arguição de Descumprimento de Preceito Fundamental $\mathrm{n}^{\circ}$ 132, do Rio de Janeiro, julgada em: 05/05/2011, pelo Supremo Tribunal Federal. Disponível em: <http://www.stf.jus.br/portal/cms/verNoticiaDetalhe.asp? idConteudo=178792\&caixaBusca=N $>$ Acesso em: 25 jul. 2011.

${ }^{14}$ BARROSO, Luís Roberto. Diferentes, mas iguais: o reconhecimento jurídico das relações homoafetivas no Brasil. Trabalho desenvolvido com a colaboração de Cláudio Pereira de Souza Neto, Eduardo Mendonça e Nelson Nascimento Diz. Disponível em:<http://www.Irbarroso.com.br/ pt/casos/uniao/artigo_prof_luis_roberto_barroso_diferentes_mas_iguais.pd> Acesso em: 20 jul. 2011. ${ }_{15}$ DOTTI, Rogéria. O Direito à Dignidade. Gazeta do Povo, Curitiba, 03 maio 2011. Caderno Vida e Cidadania, p. 2.
} 
Mais do que isso, a discussão acerca da decisão do Supremo avançou sobre páginas de jornais, sítios na internet, redes sociais, salas de aula e editoriais, sempre envolta por uma série de dúvidas e de questionamentos de natureza organizacional.

\section{USURPAÇÃO DA COMPETÊNCIA LEGISLATIVA?}

A sociedade civil, após a decisão do Supremo Tribunal Federal que reconheceu a possibilidade da união de pessoas do mesmo sexo caracterizar união estável, discutiu, em amplo espectro, se houve invasão da esfera de competência do Poder Legislativo ou uma suposta violação ao princípio da separação dos poderes. Além disso, questionou-se muito se a decisão teria apenas aplicado o disposto no artigo $4^{\circ}$ da Lei de Introdução às normas do Direito Brasileiro ${ }^{16}$, o qual estabelece que o juiz deve decidir o caso de acordo com a analogia, os costumes e os princípios gerais de direito quando a lei for omissa, ou se, de fato, a decisão refletia a usurpação do poder legislativo pelo Judiciário.

O modelo sobre o qual se desenvolveu a cultura jurídica brasileira no século $X X$ é o dogmático e lógico-formal, fundado na crença no equilíbrio entre os poderes e na separação entre direito público e direito privado. Como a edição das leis coube ao Legislativo, neste modelo restou ao Executivo e ao Judiciário o dever de execução e aplicação das normas de modo objetivo. $^{17}$ De acordo com Luiz Guilherme Marinoni, a preocupação no desenvolvimento de um novo Direito a partir da Revolução Francesa é o fator que acarretou na admissão dos argumentos de Montesquieu sobre separação de poderes, culminando nesta clara distinção entre as funções legislativa e judiciária. O autor ressalta que neste período "Tornou-se imprescindível limitar a atividade do judiciário, subordinando-o de forma rígida ao Parlamento, cujos habitantes deveriam representar os anseios do povo."18 Esta concepção perpetuou por longo período e, de certo modo, pode-se dizer que está enraizada na percepção brasileira sobre o Direito, como uma espécie de dogma.

Ocorre que no Estado moderno o Poder Judiciário deixa de ser visto como um poder nulo, cujos membros representariam apenas a boca que pronuncia a lei. ${ }^{19}$ Houve uma evolução tanto da sociedade quanto da

\footnotetext{
${ }^{16}$ BRASIL. Decreto-Lei no 4.657, de 4 de setembro de 1942, Lei de Introdução às normas do Direito Brasileiro. Disponível em: <http://www.planalto.gov.br/ccivil_03/Decreto-Lei/Del4657.htm> Acesso em: 01 ago. 2011.

17 FARIA, José Eduardo; LOPES, José Reinaldo de Lima. Pela Democratização do Judiciário. In: FARIA, José Eduardo. Direito e Justiça: a função social do Judiciário. São Paulo: Ática, 1989. p. 159-161.

18 MARINONI, Luiz Guilherme. Precedentes Obrigatórios. São Paulo: Revista dos Tribunais, 2010. p. 52-53.

${ }^{19}$ Montesquieu afirmou que: "Nos Estados despóticos, não há lei: o juiz é ele mesmo sua própria regra. Nos Estados monárquicos, existe uma lei: e onde ela é precisa o juiz segue-a; onde ela não é, ele procura seu espírito. No governo republicano, é da natureza da constituição que os juízes sigam a letra da lei. Não há cidadão contra quem se possa interpretar uma lei
} 
percepção sobre o Direito e os instrumentos de organização social. Um dos aspectos relevantes para essa mudança de mentalidade suscitado por Marinoni é a consciência de que para que o poder do magistrado se limitasse à mera repetição da lei, seria fundamental que a legislação fosse clara e apta a regular todas as situações conflitivas ${ }^{20}$ É evidente, contudo, a impossibilidade de previsão pelo ordenamento jurídico de todas as possíveis lides decorrentes das mais diversas relações humanas, pelo que, neste sentido, o Estado moderno demandou uma evolução da compreensão da função jurisdicional.

Outro fator impactante para o aprimoramento dos contornos da função judiciária é o constitucionalismo. As Constituições passaram a reunir princípios que não mais poderiam ser violados pela legislação ordinária, passando-se à conclusão de que "A Constituição é dotada de plena eficácia normativa, e, assim, a lei perde o seu posto de supremacia, passando a se subordinar a ela." ${ }^{21}$ Como pondera Marinoni, a lei não vale mais por si, uma vez que passa a encontrar limites e contornos nas Constituições dos Estados, podendo-se afirmar que:

O juiz que controla a constitucionalidade da lei obviamente não é submetido à lei. O seu papel, como é evidente, nega a ideia de supremacia do legislativo. Lembre-se que o juiz, mediante as técnicas da interpretação conforme a Constituição e da declaração parcial de nulidade sem redução de texto, confere à lei sentido distinto do que lhe deu o legislativo. A feição judicial da imposição do direito também é clara - ou ainda mais evidente - ao se prestar atenção na tarefa que o juiz exerce quando supre a omissão do legislador diante dos direitos fundamentais. Ora, isso apenas pode significar, aos olhos dos princípios e da tradição do civil law, uma afirmação do poder judicial com força de direito, nos moldes do que se concebeu no common law. ${ }^{22}$

Note-se que o ativismo legislativo, afastado da ideia originária da tripartição de poderes, não é privilégio do Poder Judiciário. O Poder Executivo, por exemplo, abusa do instituto das medidas provisórias para fins de regulação da sociedade, principalmente no âmbito da economia. ${ }^{23}$ No exercício das suas funções, todos os Poderes, em maior ou em menor grau, praticam atos inerentes à competência dos demais, ingerência que não representa nenhuma irregularidade, sendo que o próprio Legislativo também exerce funções inerentes à competência dos demais Poderes.

quando se trata de seu bens, de sua honra ou de sua vida." (MONTESQUIEU, Baron de (Charles de Secondat). O espírito das leis. São Paulo: Martins Fontes, 1996. p. 87).

${ }^{20}$ MARINONI, Luiz Guilherme, op. cit., p. 54.

${ }^{21}$ Ibid., p. 67.

${ }^{22}$ Ibid., p. 69.

${ }^{23}$ VIANNA, Luiz Werneck; CARVALHO, Maria Alice Resende; MELO, Manuel Palacios Cunha; BURGOS, Marcelo Baumann. A Judicialização da Política e das Relações Sociais no Brasil. Rio de Janeiro: Revan, 1999. p. 49. 
José Reinaldo de Lima Lopes, ao tratar da função judiciária de resolução de conflitos, afirma que "Quando o Judiciário toma conhecimento de demandas potencialmente públicas ou politizáveis ele procede objetivamente à integração do conflito à órbita jurídica e retira-lhe o caráter político.", defendendo que "Quando os conflitos não têm expressão jurídica tornam-se políticos, quando encontram uma expressão jurídica são despolitizados." ${ }^{24}$ Tal contexto, contudo, não se coaduna com a questão da decisão do Supremo Tribunal Federal sobre a união homoafetiva, na medida em que a interpretação dada pelo Supremo teve evidentes implicações político-sociais, inclusive quanto aos seus desdobramentos em relação a outros institutos jurídicos, tais como o casamento civil.

A despeito dos resultados de natureza política e social, a decisão do Supremo Tribunal Federal objeto do presente estudo não importa em uma indevida usurpação da competência do Poder Legislativo, mas, ao contrário, apenas reflete o legítimo exercício da competência jurisdicional que é atribuída à Corte Constitucional brasileira pela Constituição da República.

\section{O PODER JUDICIÁRIO NO ESTADO MODERNO}

O Estado do Bem-Estar Social, considerado como uma das mais bem-sucedidas construções da civilização ocidental ao agregar ideais de liberdade, democracia, valorização da pessoa humana e do trabalho, justiça social e bem-estar das populações, surgiu com a ascensão à arena política e social da grande massa de trabalhadores pobres e excluídos a partir da segunda metade do século XIX e desenvolveu-se no século XX nos países líderes do capitalismo na Europa e nos EUA a partir da década de $1930 .{ }^{25}$

Este novo modelo de Estado constitui-se com a intervenção do Poder Legislativo de modo a sujeitar a economia e o mercado de trabalho à jurisdição da Administração Pública e de suas normas, ensejando, assim, a reconfiguração das relações entre direito público e privado. ${ }^{26}$ No período subsequente à segunda guerra, o Direito Constitucional concedeu espaço aos princípios fundamentais, aos direitos sociais e às correntes do humanismo jurídico. Esta positivação de direitos fundamentais reintroduziu no Direito a ideia de justiça, antes renegada. A democratização social e a democracia política (que trouxe a lume Constituições que positivavam direitos fundamentais) redefiniram as relações mantidas entre os três Poderes, ensejando a inclusão do Poder Judiciário no âmbito da política. ${ }^{27}$

\footnotetext{
${ }^{24}$ LOPES, José Reinaldo de Lima. A Função Política do Poder Judiciário. In: FARIA, José Eduardo. Direito e Justiça: a função social do Judiciário. São Paulo: Ática, 1989. p. 139-140.

${ }^{25}$ DELGADO, Maurício Godinho; PORTO, Lorena Vasconselos. O Estado de Bem-estar Social no Capitalismo Contemporâneo. Revista de Direito do Trabalho, São Paulo, v. 128, p. 155 et seq., out. 2007.

${ }^{26}$ VIANNA, Luiz Werneck; CARVALHO, Maria Alice Resende; MELO, Manuel Palacios Cunha; BURGOS, Marcelo Baumann, op. cit., p. 17.

${ }^{27}$ Ibid., p. 21-22.
} 
Mauro Cappelletti ressalta que, após a segunda grande guerra, progressivamente consolidou-se o fenômeno (de proporções universais) chamado constitucionalismo moderno. Para o autor, trata-se de uma grande revolução, que acarreta na substituição da ideia da rígida separação de poderes, da não interferência e da supremacia do poder político para abraçar uma proposta de recíproco controle e equilíbrio dos poderes. A Constituição brasileira se amolda a esta tendência contemporânea que tem modificado a forma de governo nos países liberal-democráticos modernos. ${ }^{28}$

Este constitucionalismo moderno agrega o sistema de controles recíprocos comumente identificado pela expressão checks and balances, ou seja, a limitação do poder político pela existência de uma lei hierarquicamente superior e o dever de guarda destas normas pelos magistrados. O sistema de checks and balances, segundo Eugenio Raúl Zaffaroni, não é nada mais do que uma distribuição do poder político, na medida em que o Poder Judiciário, por cumprir função política, é também politizado. ${ }^{29}$

Assim, o Estado moderno demanda do magistrado uma atuação muito mais significativa do que a mera aplicação literal da lei. Neste sentido, Oriana Piske de Azevedo Magalhães Pinto afirma que:

O juiz contemporâneo, seja porque só está vinculado à lei constitucionalmente válida, seja porque enfrenta freqüentemente conceitos jurídicos indeterminados, principalmente quando deve solucionar conflitos modernos relacionados com relações de consumo, com o meio ambiente, interesses difusos etc., é integrante do centro de produção normativa, logo, é um juiz politizado (o que não se confunde com politização partidária). O Juiz, no nosso sistema judicial, sem extrapolar o marco jurídico-constitucional, pode e deve desempenhar sua tarefa de dirimir litígios de modo socialmente mais justo cumprindo papel inteiramente distinto do juiz legalista-positivista, criado pela Revolução Francesa para ser la bouche de la loi [a boca da lei]. ${ }^{30}$

Conforme este entendimento, a atuação mais incisiva e participativa do magistrado decorre da existência de um caráter intrinsecamente político no exercício da função jurisdicional na atual sociedade, função que é reiteradamente pautada em conceitos abertos, que impõem (e legitimam) o uso de técnicas interpretativas pelos magistrados. Ao mesmo tempo em que são positivados direitos fundamentais de caráter amplo e de conceitos abertos,

28 CAPPELLETTI, Mauro. Constitucionalismo Moderno e o Papel do Poder Judiciário na Sociedade Contemporânea. Revista de Processo, São Paulo, v. 60, p. 110 et seq., out. 1990.

${ }_{29}$ ZAFFARONI, Eugenio Raúl. Poder Judiciário: crise, acertos e desacertos. Traduzido por: Juarez Tavares. São Paulo: Revista dos Tribunais, 1995. p. 94.

${ }^{30}$ PINTO, Oriana Piske de Azevedo Magalhães. A Essência da Independência e da Legitimação Democrática da Atividade Judicial. In: Instituto de Direito Comparado e Internacional de Brasília. Disponível em: <http://uww.idcb.org.br/index.php?option=com_content\&view=article\&id=76:a-essenciada-independencia-e-da-legitimacao-democratica-da-atividade-judicial\&catid=30:outros\&ltemid=37> Acesso em: 02 ago. 2011. 
demanda-se do juiz o exercício um esforço interpretativo muito maior do que historicamente se exigiu, a fim de garantir a eficácia e a adequada compreensão sobre estes mesmos direitos, o que culmina na judicialização de temas de caráter iminentemente político-social.

Ao tratar do papel dos magistrados, Mauro Cappelletti ressalta ainda que "[...] estamos diante de dois perigosos gigantes do moderno 'Leviatã': o gigante legislador - com competência sempre mais vasta, em outras épocas até ignorada pela lei - e o gigante administrador - também este com influência enormemente ampliada naquilo que o estado chamou de 'Estado Providência' (providencial, oportuno), ou Welfare State, o moderno Estado social do direito."31 Neste modelo, no qual o poder público é exponencialmente aumentado, é necessária a imposição de limites à atuação do legislador e do administrador, responsabilidade que somente poderia ser atribuída ao Judiciário.

Luiz Werneck Vianna e coautores descrevem o fenômeno da hodierna atuação judicial afirmando que:

Em torno do Poder Judiciário vem-se criando, então, uma nova arena pública, externa ao circuito clássico "sociedade civil - partidos representação - formação da vontade majoritária", consistindo em ângulo perturbador para a teoria clássica da soberania popular. Nessa nova arena, os procedimentos políticos de mediação cedem lugar aos judiciais, expondo o Poder Judiciário a uma interpelação direta de indivíduos, de grupos sociais e até de partidos - como nos casos de países que admitem o controle abstrado de normas -, em um tipo de comunicação em que prevalece a lógica dos princípios, do direito material, deixando-se para trás as antigas fronteiras que separavam o tempo passado, de onde a lei geral e abstrata hauria seu fundamento, do tempo futuro, aberto à infiltração do imaginário, do ético e do justo. ${ }^{32}$

Muitas críticas, contudo, são feitas a este formato de atuação do Poder Judiciário. A resposta às alegações de que os juízes não teriam legitimidade democrática para exercer o controle das leis no Estado moderno é apresentada por Cappelletti na forma de decálogo, cujos mandamentos pautam-se, principalmente, sobre: a necessidade preeminente de controle e de aplicação dos direitos constitucionais, mesmo que em detrimento da maioria; o fato de ser o processo judicial um núcleo fundamental da democracia; o exercício de um controle social sobre o magistrado; a garantia democrática à tutela jurisdicional e a busca por um sistema eficaz. ${ }^{33}$

Se nas teorias clássicas o papel do juiz era o de declarar a lei ou de criar uma norma individual a partir de uma norma geral, atualmente 0

${ }^{31}$ CAPPELLETTI, Mauro, op. cit., p. 110 et seq.

${ }^{32}$ VIANNA, Luiz Werneck; CARVALHO, Maria Alice Resende; MELO, Manuel Palacios Cunha; BURGOS, Marcelo Baumann, op. cit., p. 22-23. Grifos do autor.

${ }^{33}$ CAPPELLETTI, Mauro, op. cit., p. 110 et seq. 
magistrado é imbuído da função de construir a norma jurídica a partir da interpretação de acordo com a Constituição, do controle de constitucionalidade e da regra de proporcionalidade (balanceamento) dos direitos fundamentais no caso concreto. ${ }^{34}$

É evidente que o Judiciário exerce função política, a qual, segundo José Reinaldo de Lima Lopes, deriva da sua própria inserção no Estado. ${ }^{35}$ Zaffaroni destaca esta atuação politizada dos juízes afirmando que "Cada sentença é um serviço que se presta aos cidadãos, mas também é um ato de poder e, portanto, um ato de governo, que cumpre a importante função de prover a paz interior mediante a decisão judicial de conflitos.", pelo que conclui que "A participação judicial no governo não é um acidente, mas é da essência da função judiciária: falar de um poder do Estado que não seja político é um contra-senso." 36

Roger Stiefelmann Leal pondera que o Judiciário passou a ser encarado como o escudo da sociedade, o qual protege os direitos individuais contra os avanços do Estado, o que acarretou em uma maior ingerência deste Poder sobre os demais, ao que se atribui o nome de judicialização da política. $\mathrm{O}$ autor ensina que:

O controle dos atos administrativos e o controle da constitucionalidade das leis e atos normativos juntamente ao processo de ampliação do "campo" constitucional conferiram uma enorme esfera de poder aos órgãos jurisdicionais, ocasionando uma inevitável supremacia do Poder Judiciário que, inclusive, o torna mediador político no embate entre os poderes. É necessário que se observe que quanto mais um poder prepondera, mais vulnerável ele se torna a uma eventual politização. [...] As técnicas desenvolvidas a partir da possibilidade de se controlar os demais poderes, tais como o desvio de poder e a interpretação conforme a Constituição, são sinais evidentes de uma politização da justiça proveniente da judicialização da política. Ora, tendo assumido o papel de resolver os conflitos existentes entre os poderes, agindo como árbitro do jogo político, os tribunais vêem-se na iminência da politização, ou seja, no dizer de Loewenstein, os detentores do poder, politicamente responsáveis - governo e parlamento - estão expostos à tentação de levar ante o tribunal um conflito político. Os juízes, por sua vez, estão obrigados a substituir as decisões dos responsáveis detentores do poder por seus juízos políticos, camuflados em forma de sentença judicial. ${ }^{37}$

\footnotetext{
${ }_{35}^{34}$ MARINONI, Luiz Guilherme, op. cit., p. 91.

${ }^{35}$ José Reinaldo de Lima Lopes afirma expressamente que: "A função política do Judiciário deriva de sua própria inserção no Estado." (LOPES, José Reinaldo de Lima. A Função Política do Poder Judiciário. In: FARIA, José Eduardo. Direito e Justiça: a função social do Judiciário. São Paulo: Ática, 1989. p. 141.).

${ }^{36}$ ZAFFARONI, Eugenio Raúl, op. cit., p. 94.

37 LEAL, Roger Stiefelmann. A Judicialização da Política. Revista de Direito Constitucional e Internacional, São Paulo, v. 29, p. 230 et seq., out. 1999.
} 
A judicialização da política e das relações sociais é conceituada por Luiz Werneck Vianna e outros autores como "[...] a delegação da vontade do soberano a um corpo especializado de peritos na interpretação do direito e a 'substituição' de um Estado benefactor por uma justiça providencial e de moldes assistencialistas [...]."38 Por sua vez, Eugenio Raúl Zaffaroni ressalta o entendimento de que a função política vital do juiz é a de conservar sistema, ao passo que os demais Poderes ocupam-se da função de instrumentalizar ou usar o sistema. ${ }^{39}$ Assim, em que pese o Judiciário não possua membros eleitos, não é antidemocrático, uma vez que materializa o sistema de checks and balances e protege as minorias, pelo que passa a ter importância fundamental na garantia de novos direitos e na consolidação da democracia. ${ }^{40}$

Mas a judicialização da política aproxima-se mais de um indesejado antagonismo da política ou trata-se do legítimo exercício de uma competência constitucional?

A representação, como pondera Paulo Bonavides, é inseparável da caracterização do Estado moderno, sendo o princípio representativo o alicerce legitimador do exercício normal dos Poderes. O autor afirma que "Os canais comunicativos com que a vontade de governantes e governados opera na esfera de suas relações recíprocas definem, de certo modo, o regime da autoridade pública e o estatuto da organização democrática do Estado.". Assim, "Coradas por distintas tonalidades doutrinárias e ideológicas, as diversas variantes institucionais da representação personalizam o modelo ocidental. ${ }^{" 11}$ A representatividade, na conjuntura do Estado moderno, é, portanto, o que legitima o exercício dos Poderes de Estado.

No Brasil, o efetivo exercício da democracia requer "[...] ao lado da correção das desigualdades sociais, o fortalecimento das instituições legislativas e o adensamento das diferentes formas de participação política, em condições de propiciar aos grupos, categorias e classes economicamente desfavorecidos maior representatividade nos círculos de poder., ${ }^{, 2} \mathrm{O}$ contexto social brasileiro inspira uma atuação diferenciada dos magistrados para que se efetivem os direitos humanos fundamentais prescritos na Constituição da República.

Vale destacar a observação de Luís Roberto Barroso de que "A interpretação constitucional, como a interpretação jurídica em geral, não é um exercício abstrato de busca de verdades universais e atemporais.

\footnotetext{
${ }^{38}$ VIANNA, Luiz Werneck; CARVALHO, Maria Alice Resende; MELO, Manuel Palacios Cunha; BURGOS, Marcelo Baumann, op. cit., p. 43.

${ }^{39}$ ZAFFARONI, Eugenio Raúl, op. cit. p. 187.

40 LAGE, Lívia Regina Savergnini Bissoli. O Novo Papel do Judiciário e a Teoria da Separação dos Poderes: judicialização de direitos? Revista de Processo, São Paulo, v. 184, p. 163 et seq., Jun. 2010.

${ }^{41}$ BONAVIDES, Paulo. A Constituição Aberta: temas políticos e constitucionais da atualidade. Belo Horizonte: Del Rey, 1993. p. 251.

${ }^{42}$ FARIA, José Eduardo. A Crise Constitucional e a Restauração da Legitimidade. Porto Alegre: Sergio Antonio Fabris, 1985. p. 11.
} 
Toda interpretação é produto de uma época, de um momento histórico, e envolve as normas jurídicas pertinentes, os fatos a serem valorados, as circunstâncias do intérprete e o imaginário social." ${ }^{43}$ Tal circunstância contribui com a percepção dos motivos pelos quais somente na segunda década do século XXI foram estendidos às uniões de pessoas do mesmo sexo os direitos há muito tempo garantidos aos casais heterossexuais.

\section{CONCLUSÃo}

O Supremo Tribunal Federal, ao adotar a técnica da interpretação conforme a Constituição para assegurar direitos a pessoas desamparadas pelo ordenamento jurídico brasileiro, não extrapola o seu âmbito de atuação, tampouco se apropria da competência atribuída aos demais Poderes. O STF, ao reconhecer as uniões estáveis formadas por pessoas do mesmo sexo, atuou dentro dos limites de sua competência de modo a garantir a efetividade dos direitos humanos expressos na Constituição da República.

Verifica-se que a nova ordem Constitucional e a hodierna realidade de vulnerabilidade e desigualdades que a assola grande parte da população brasileira demandam do magistrado, independentemente do Tribunal ou Corte no qual esteja inserido, que interprete as leis e normas jurídicas de modo a efetivar os preceitos constitucionais fundamentais. A chamada politização é, na verdade, inerente à função jurisdicional, a qual é exercida, em última análise, em prol dos jurisdicionados e, consequentemente, de toda a sociedade. Os demais Poderes, em especial o Poder Legislativo, podem atuar concomitantemente na efetivação de direitos, no entanto, necessariamente sofrerão legítimas limitações impostas não pelo Poder Judiciário, mas sim pela Carta Magna.

Assim, a decisão do Supremo de reconhecer a união estável formada por pessoas do mesmo sexo é resultado da mudança imposta pelo fenômeno moderno da constitucionalização de direitos fundamentais, da evolução da compreensão sobre a função judicial e do fenômeno da judicialização da política.

\section{REFERÊNCIAS}

BARROSO, Luís Roberto. Diferentes, mas Iguais: o reconhecimento jurídico das relações homoafetivas no Brasil. Trabalho desenvolvido com a colaboração de Cláudio Pereira de Souza Neto, Eduardo Mendonça e Nelson Nascimento Diz. Disponível em: <http://www.Irbarroso.com.br/pt/casos/uniao/ artigo_prof_luis_roberto_ barroso_diferentes_mas_iguais.pd> Acesso em: 20 jul. 2011.

BRASIL. Constituição da República Federativa do Brasil de 1988. Disponível em: http://www.planalto.gov.br/ccivil_03/constituicao/constitui\%C3\%A7ao.htm Acesso em: 01 ago. 2011.

${ }^{43}$ BARROSO, Luís Roberto. Diferentes, mas Iguais: o reconhecimento jurídico das relações
homoafetivas no Brasil. Trabalho desenvolvido com a colaboração de Cláudio Pereira de Souza
Neto, Eduardo Mendonça e Nelson Nascimento Diz. Disponível em:<http://www.Irbarroso.com.br/
pt/casos/uniao/artigo_prof_luis_roberto_barroso_diferentes_mas_iguais.pd> Acesso em: 20 jul. 2011. 
BRASIL. Decreto-Lei no 4.657 , de 4 de setembro de 1942, Lei de Introdução às normas do Direito Brasileiro. Disponível em: <http://www.planalto.gov.br/ccivil_03/ Decreto-Lei/Del4657.htm> Acesso em: 01 ago. 2011.

BRASIL. Supremo Tribunal Federal, Arguição de Descumprimento de Preceito Fundamental $n^{\circ}$ 132, do Rio de Janeiro. Relator: Min. Ayres Britto, julgada em: 05.05.2011. Disponível em: <http://redir.stf.jus.br/estfvisualizadorpub/jsp/consultarprocessoeletronico/ ConsultarProcessoEletronico.jsf?seqobjetoincidente=11872 > Acesso em: 20 jul. 2011.

BONAVIDES, Paulo. A Constituição Aberta: temas políticos e constitucionais da atualidade. Belo Horizonte: Del Rey, 1993.

CAPPELLETTI, Mauro. Constitucionalismo Moderno e o Papel do Poder Judiciário na Sociedade Contemporânea. Revista de Processo, São Paulo, v. 60, p. 110 et seq., out. 1990.

DELGADO, Maurício Godinho; PORTO, Lorena Vasconselos. O Estado de Bem-estar Social no Capitalismo Contemporâneo. Revista de Direito do Trabalho, São Paulo, v. 128, p. 155 et seq., out. 2007.

DOTTI, Rogéria. O Direito à Dignidade. Gazeta do Povo, Curitiba, 03 maio 2011. Caderno Vida e Cidadania, p. 2.

FARIA, José Eduardo. A Crise Constitucional e a Restauração da Legitimidade. Porto Alegre: Sergio Antonio Fabris, 1985.

Direito e Justiça: a função social do Judiciário. São Paulo: Ática, 1989.

.; LOPES, José Reinaldo de Lima. Pela democratização do Judiciário. In: FARIA, José Eduardo. Direito e Justiça: a função social do Judiciário. São Paulo: Ática, 1989.

LAGE, Lívia Regina Savergnini Bissoli. O Novo Papel do Judiciário e a Teoria da Separação dos Poderes: judicialização de direitos? Revista de Processo, São Paulo, v. 184, p. 163 et seq., jun. 2010.

LEAL, Roger Stiefelmann. A Judicialização da Política. Revista de Direito Constitucional e Internacional, São Paulo, v. 29, p. 230 et seq., out. 1999.

LOPES, José Reinaldo de Lima. A Função Política do Poder Judiciário. In: FARIA, José Eduardo. Direito e Justiça: a função social do Judiciário. São Paulo: Ática, 1989. MARINONI, Luiz Guilherme. Precedentes Obrigatórios. São Paulo: Revista dos Tribunais, 2010.

MATOS, Miguel. Migalhas de Rui Barbosa. v. 1. São Paulo: Migalhas, 2010.

MONTESQUIEU, Baron de (Charles de Secondat). O Espírito das Leis. São Paulo: Martins Fontes, 1996.

NERY JUNIOR, Nelson. Princípios do Processo na Constituição Federal: processo civil, penal e administrativo. 9. ed. rev., atual. e amp. São Paulo: Revista dos Tribunais, 2009.

PINTO, Oriana Piske de Azevedo Magalhães. A essência da independência e da legitimação democrática da atividade judicial. In: Instituto de Direito Comparado e Internacional de Brasília. Disponível em: <http://wwww.idcb.org.br/index.php?option= com_ content\&view=article\&id=76:a-essencia-da-independencia-e-da-legitimacao-democraticada-atividade-judicial\&catid=30:outros\&ltemid=37> Acesso em: 02 ago. 2011.

REALE, Miguel. Liberdade e Democracia: em torno do anteprojeto da Comissão Provisória de Estudos Constitucionais. São Paulo: Saraiva, 1987. 
VIANNA, Luiz Werneck; CARVALHO, Maria Alice Resende; MELO, Manuel Palacios Cunha; BURGoS, Marcelo Baumann. A Judicialização da Política e das Relações Sociais no Brasil. Rio de Janeiro: Revan, 1999.

Voto do senhor Ministro Ayres Britto no julgamento da Arguição de Descumprimento de Preceito Fundamental $\mathrm{n}^{\circ}$ 132, do Rio de Janeiro, julgada em: 05.05.2011, pelo Supremo Tribunal Federal. Disponível em: <http://www.stf.jus.br/portal/cms/ verNoticiaDetalhe.asp?idConteudo=178792\&caixaBusca=N> Acesso em: 25 jul. 2011.

ZAFFARONI, Eugenio Raúl. Poder Judiciário: crise, acertos e desacertos. Traduzido por: Juarez Tavares. São Paulo: Revista dos Tribunais, 1995. 